\title{
IMPROVE COGNITIVE ABILITIES AND LEARNING MOTIVATION STUDENT IN ELEMENTARY SCHOOL WITH SCIENTIFIC APPROACHES AND STORYTELLING ACTIVITIES.
}

\author{
Septina Severina Lumban Tobing \\ 'Phsycal Education Department, Faculty of Teacher Training and Education, Universitas Kristen \\ Indonesia, Indonesia \\ $\bowtie$ septinaseverina@gmail.com
}

\begin{abstract}
This research has been conducting to get a picture of improving cognitive abilities and learning motivation of students who get natural science subjects in elementary schools with a scientific approach and storytelling activities. The study has been conducting using quasi-experimental methods with a randomized one-group pretest-posttest design. The population is all grade IV students of SD Negeri 7 Jakarta. A sample of one class has been selecting by random cluster sampling. The sample of this research was class IV C, with 30 students. Test instruments in the form of essay tests were 15 items, and learning motivation questionnaires were 12 items with five options using the Likert Scale. The data has been processing with the help of SPSS 22 software. The results showed that there was an increase in students' cognitive abilities with a gain value of 0.55 in the medium category. Student learning motivation has been obtaining an increase of $85.76 \%$ in the top category.
\end{abstract}

Keywords: Cognitive Abilities; Motivation; Scientific Approach, Storytelling.

INTRODUCTION In Natural Sciences (IPA) is a compulsory subject in every Elementary School in Indonesia. Nevertheless, understanding and curiosity about science among students are still low. The results of studies on the quality of education conducted by the Political and Economic Risk Consultancy (PERC), which Indonesia ranks $160^{\text {th }}$ in the world and 12 thin Asia, Indonesia's position is below Vietnam. Data reported by The World Economic Forum Sweden (2000) also states that Indonesia has low competitiveness, which only ranks 37 th out of 57 countries surveyed in the world.

Natural Sciences (IPA) is a concept of natural learning and has an extensive relationship related to human life. Also, science subjects become a pillar to help understand other subjects. Student mastery of science lessons is also a benchmark of technological mastery in the future. Therefore, the delivery of natural science subjects needs to be designed in such a way so that it can be studied to the maximum and has been expecting to be a vehicle for students to learn themselves and the natural surroundings. Ministry of National Education (2004) mentions that one of the elementary subjects that needs special attention is the Natural Sciences or science. According to Ahmadi (1991), the beginning of natural science begins when humans pay attention to natural phenomena, record them, and then study them. The knowledge gained was initially limited to observations of natural phenomena that were then further increased by the knowledge gained from the results of his thoughts. Moreover, after that, humans can do experiments to prove and seek the truth of knowledge.

However, science lessons are painful for students to understand because there are several abstract problems, while elementary school children tend to 
understand something real more easily. Schools place more emphasis on numeracy skills and pay less attention to activities that stimulate children's cognitive abilities and motivations, causing essential concepts in science lessons that should invite reasoning students to disappear. The results that the lack of cognitive abilities and motivation of students. From the results of the Trends in International Mathematics and Science Study (TIMSS) conducted by the International

The government, through the implementation of the 2013 curriculum in each school, is one solution to help students to understand science lessons better. In the 2013 curriculum, learning has been designing with a scientific approach where students are required to be able to develop their scientific abilities. Daryanto (2014) states learning with a scientific approach is a learning process that has been designing so that students actively construct concepts through the stages of observing, formulating problems, proposing hypotheses, collecting data, analyzing data, drawing conclusions, and communicating the concepts found.

In addition to factors in the learning process that are less innovative in the classroom, low cognitive abilities and student motivation have been influencing by other things. According to Sumiati (2011), one of the reasons why students are less successful in learning is because they have difficulty reading textbooks. So sometimes children feel bored, lazy, not interested in what taught, maybe even oppose and rebel. It also causes students to be less motivated in learning. Motivation is a process that gives enthusiasm, direction, and persistence in
Association for Educational Achievement (IEA) conducted in 2015, elementary school students in Indonesia only rank 45 out of 48 countries in natural science abilities. The low achievement of students has been influencing by several factors, including the ability of teachers to understand and follow curriculum development, the role of stimulus from parents, and the application of learning models that are not innovative.

behavior. That is, motivated behavior is behavior that is full of energy, directed, and enduring (Santrock, 2010). A teacher not only acts as a facilitator and mediator but is also required to be able to act as a motivator that can arouse students 'enthusiasm and encouragement in learning by using a variety of appropriate teaching skills and support the formation of students' basic competencies better in terms of knowledge, skills, and attitudes.

Therefore, it is necessary to introduce more enjoyable methods, such as storytelling. Storytelling is an activity that someone does verbally to others with tools about what should have been delivering in the form of messages, information, or just a fairy tale that has been packaging in the form of stories that can listen to with a sense of fun (Madyawati L, 2016). Also, according to Arini (2011) states that storytelling activities can provide entertainment and stimulation of children's imagination. Through storytelling activities in the learning process in class, students have been introducing to science concepts in a fun way. Storytelling in science learning can also stimulate students to reason about a natural phenomenon by telling stories about their own experiences and observations. Based on the background of the problems that 
have been describing, then in general, the purpose of this study is to find out "how to improve students' cognitive abilities and motivation after getting a scientific learning approach combined with storytelling activities?".

\section{RESEARCH METHODS}

In this study, the method used was a quasiexperimental design using a randomized one group pretest-posttest design
(Arikunto, 2006). This research has been conducting at SD Negeri 7 Jakarta in the $2019 / 2020$ school year. The population in this study were all grade IV students, amounting to 3 classes. The sampling technique was random cluster sampling, in which the sample of the study was the IV $C$ class with 30 students. The research sample consisted of 22 girls' students and 18 boys' students.

Tabel 1. Research Design

\begin{tabular}{lll}
\hline Pretest & Treatment & Posttest \\
\hline $\mathrm{T} 1$ & $\mathrm{X}$ & T2 \\
\hline
\end{tabular}

Information:

$\mathrm{Tl}=$ Test before treatment

$X=$ Treatment in the form of applying the scientific approach with storytelling activities.

$\mathrm{T} 2=$ Test after treatment

The instruments in this study consisted of test and non-test instruments. The test instrument is a cognitive ability test in the form of an essay test. Cognitive ability tests include Bloom's Taxonomy rules from the realm of $\mathrm{C} 1$ to $\mathrm{C} 4$ (Anderson \& Krathwohl,

Indicators, namely the presence of students' curiosity, concentration on teaching materials, active in asking and answering questions, and being able to work in teams. The questionnaire consisted of 12 statements, both positive and negative statements, and was measured using a Likert scale. Student questionnaire data on learning motivation was analyzed by calculating the percentage of statement items and analyzed by comparing the tendencies of positive attitudes and negative attitudes of students. The student questionnaire data is
2001). Provision of tests carried out two times, namely pretest and posttest. The pretest has been giving before the class has been giving treatment intending to know students' initial cognitive abilities. Then the class is given treatment with the application of the scientific learning approach combined with storytelling activities. After the class has been giving treatment, then given a posttest to see how much improvement in students' cognitive abilities. For non-test instruments.

processed using the formula:

$\%$ motivation $=\frac{\sum \text { student answer score }}{\sum \text { score maximum }} \times 100 \%$ with the numbers $0 \%-20 \%=$ very less, $21 \%$ $-40 \%=$ less, $41 \%-60 \%=$ enough, $61 \%-80 \%$ = good, $81 \%-100 \%=$ very good.

The analysis technique used in this study to calculate how much the increase in cognitive abilities after learning with a scientific approach and storytelling has been obtaining by calculating the average value of the normalized gain / $\mathrm{N}$ gain (Hake, 1999) used, namely: 


$$
g=\frac{\text { score posttest }- \text { score pretest }}{\text { score } \max -\text { score pretest }}
$$

with $(<g>)<0.3$ in the low category; $0.3 \leq$ $(<\mathrm{g}>)<0.7$ moderate category; and $(<\mathrm{g}>)$ $\geq 0.7$ with the high category.

\section{RESULTS}

The purpose of this research is to see an increase in students' cognitive and motivational abilities after applying a scientific approach and storytelling activities. Data on the results of increasing cognitive abilities have been obtaining from the pretest and posttest scores. The average score of pretest, posttest, and average normalized gain $\langle\mathrm{g}\rangle$ can see in Table 1.

Tabel 2. Pretest and Posttest Result for Cognitive Abilities

\begin{tabular}{lll}
\hline & Pretest & Posttest \\
\hline Mean & 36,51 & 71,35 \\
Median & 36,66 & 71,00 \\
Minimum & 20,83 & 57,00 \\
Maximum & 58,67 & 90,32 \\
Std Deviasi & 9,47 & 9,62 \\
\hline
\end{tabular}

Table 1. shows the average pretest scores and posttest cognitive abilities achieved by students after applying the scientific learning approach and storytelling activities. The average pretest score of students before learning is 36.51 . It shows that the cognitive abilities of students are still minimal. The low score of students' pretests that, several factors that including the material that has not been studying before. Besides doing more conventional learning activities such as doing exercises in textbooks, re-writing lessons from the blackboard, and the teacher is still the primary source of learning. As a result of this way of learning, that the minimum score of students at the time of the pretest only stands at 20.84 , and the maximum score is only 58.6.

The average final test score (posttest) of students' cognitive abilities after learning increased to 71.35. It is because the learning process of students in the class has changed from teacher center learning to student-centered learning. When learning in class, students no longer only listen and take notes, but students must also take part in conducting learning activities.

During the learning process, the subject matter is conveyed not only through lecture activities but also using the help of instructional video media and images. By watching learning videos, students can observe well so that the lessons are no longer abstract but real or real. When students observe through video or pictures, curiosity arises from within students. It is through this curiosity that questions arise from students. Submitting questions and gathering information to find answers or solutions to these questions becomes a useful learning tool that can train students' reasoning abilities. The reasoning process is carried out in small groups in the class by discussion. To get maximum results, students not only discuss it but conduct experiments as a means of proving and practicing psychomotor skills.

The learning process during research also trains students' communication skills. Students' communication skills have been training through storytelling. Students have been asking to share the results of the discussion with their classmates in front of the class. In addition to improving communication skills, this activity is also effective in increasing students' ability to form networks between one material concept and another material concept. By being able to form a 
Network, students' vocabulary for the material has studied also becomes more and more. Due to the lack of vocabulary, students become one of the obstacles in practicing reasoning skills because students cannot convey their ideas or ideas in proper language and easy to be understood by others. Storytelling activities also increase self-confidence in students themselves. The effect of the application of scientific
Learning and storytelling activities carried out in the classroom can be seen as the minimum score of students at the posttest rises to 57.00, and the maximum value reaches 90.33 .

To see an increase in students' cognitive abilities as a whole, calculating the average normalized gain value $<\mathrm{g}>$ from the student's pretest and posttest data as in the table below.

Tabel 3. Normalized Gain Value

\begin{tabular}{lllll}
\hline & Pretest & Posttest & Gain Score & Criteria \\
\hline Sampel & 36,51 & 71,35 & 0,55 & Moderate \\
\hline
\end{tabular}

From table 2, we can see that the increase in students' cognitive abilities is in the medium category. Increased cognitive abilities of students cannot reach high criteria due to several factors. First, students are not used to learning using a scientific approach and storytelling activities so that the process in the classroom does not run smoothly. Both students are also new in terms of solving problems in the learning process because they are already familiar with the activity of taking notes and just listening without experimenting. Thirdly, the students' initial ability is also an obstacle because some students are not even fluent in reading.

\section{Descriptions of Improvement in Every Aspect of Cognitive Ability.}

To see the improvement of each student's cognitive level from $\mathrm{Cl}$ to $\mathrm{C} 4$ can see in figure 1.

Figure 1: Cognitive Level

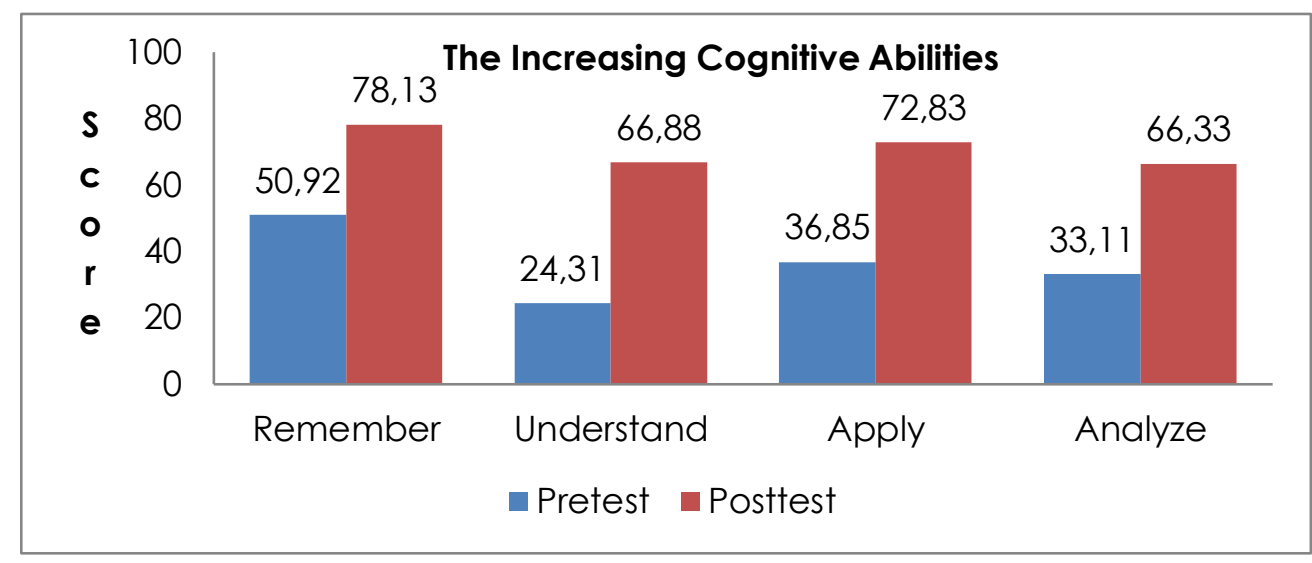

Figure 1 shows that there is an increase in each cognitive level. The increase in cognitive level $\mathrm{Cl}$ or recall experienced an increase of 27.21 points. It is because, during the learning process, students are not only asked to memorize the concept of the material but explaining through videos and pictures. Students' memories will last 
longer if appropriate learning media assist them. At the C2 level, the increase in students' cognitive abilities increased by 42.57 points. At this level, the improvement of students' abilities is quite significant because the learning process has been assessing with storytelling activities. Students have been asking to explain the material in front of the class by using language that quickly understood. Storytelling activities also add to the vocabulary of students related to the concept of the material has studied. The most noticeable difference in cognitive level improvement is at the C3 level or applying. It happens because, during the learning process with a scientific approach, the student has been training to be able to apply the concept of material to the activities experienced in everyday life. Also, students have been asking to conduct experiments to find out and prove the material learned. The lowest cognitive improvement of students is at the C4 level, and it happens because students did not accustom to analyzing to solve or find solutions to a problem.

\section{Description of Increasing Student Motivation}

To see the results of student learning motivation after learning with a scientific approach and storytelling activities distributed motivation questionnaires. The questionnaire distribution was doing at the end of the learning process after conducting a post-test. The results of the student motivation questionnaire are as in table 4.

Tabel 4. Student Motivation Questionnaires Result

\begin{tabular}{lll}
\hline $\begin{array}{l}\text { Indicator } \\
\text { Motivation }\end{array}$ & $\%$ & Criteria \\
\hline Curiosity & 86,90 & Very good \\
\hline
\end{tabular}

\begin{tabular}{lll}
\hline Concentration & 78,92 & Good \\
Asking and & 88,33 & Very good \\
Answering & & \\
Cooperation & 88,89 & Very good \\
\hline
\end{tabular}

From table 4, it can conclude that there is an increase in student motivation for all indicators. It shows that the learning process with a scientific approach and storytelling activities is quite effective in increasing student motivation.

\section{DISCUSSION}

From the results of research conducted by the elementary school to improve cognitive abilities and student motivation to study science subjects, it can see that the scientific approach and storytelling activities are very effective. By the scientific approach theory that appeals to students to become active learners. Students were training to be able to build their knowledge from the observations they do themselves.

\section{CONCLUSION}

Based on the results of research and data analysis that has been doing regarding the application of scientific approaches and storytelling activities, it concludes that this learning can further improve students' cognitive abilities with a gain value of 0.55 in the medium category and increase student motivation to $85.76 \%$ in the excellent category.

\section{REFERENCES:}

Ahmadi (1991). Psikologi Sosial. Jakarta PT Rhineka Cipta.

Arikunto, S. (2006). Dasar-dasar Evaluasi Pendidikan. Jakarta. Bumi 
Aksara

Arini, Fitri Cahyo (2011). Penerpapan Metode Paired Storytelling untuk Meningkatkan Keterampilan Berbicara Siswa Kelas V SDN Bareng 3 Kota Malang [skripsi]. Universitas Negeri Malang.

Daryanto. (2014). Pendekatan Pembelajaran Saintifik Kurikuluum 2013. Jakarta. Gaya Media

Depdiknas (2004). Kerangka Dasar kurikulum 2004. Jakarta.

Hake, R.R. (1999). Analyzing Change/Gain Score. AREA-D American education Research Association's Division Measurement and Research Methodology.

Madyawati, Lilis. (2016). Strategi Pengembangan Bahasa pada Anak. JakartaPrenadamedia Group.

Political and Economic Risk Consultancy (PERC) Score Good Corporate Governance di negara Asia tahun 2012 (www.asiarisk.com)

Santrock. (2010). Psikologi Pendidikan.Jakarta. Kencana.

Sumiati. (2011). Metode Pembelajaran. Bandung. CV Wacana Prima. 